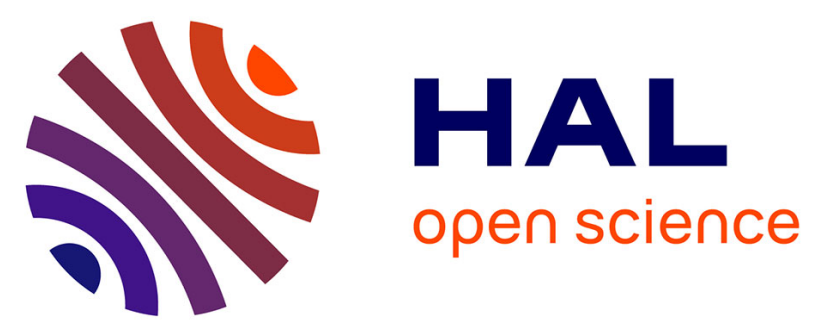

\title{
Association of surface dielectric barrier discharge and photocatalysis in continuous reactor at pilot scale: butyraldehyde oxidation, by-products identification and ozone valorization
}

\author{
Sara Gharib-Abou Ghaida, Aymen Amine Assadi, Guillerme Costa, \\ Abdelkrim Bouzaza, Dominique Wolbert
}

\section{To cite this version:}

Sara Gharib-Abou Ghaida, Aymen Amine Assadi, Guillerme Costa, Abdelkrim Bouzaza, Dominique Wolbert. Association of surface dielectric barrier discharge and photocatalysis in continuous reactor at pilot scale: butyraldehyde oxidation, by-products identification and ozone valorization. Chemical Engineering Journal, 2016, 292, pp.276-283. 10.1016/j.cej.2016.02.029 hal-01274114

HAL Id: hal-01274114

https://hal-univ-rennes1.archives-ouvertes.fr/hal-01274114

Submitted on 27 Apr 2016

HAL is a multi-disciplinary open access archive for the deposit and dissemination of scientific research documents, whether they are published or not. The documents may come from teaching and research institutions in France or abroad, or from public or private research centers.
L'archive ouverte pluridisciplinaire HAL, est destinée au dépôt et à la diffusion de documents scientifiques de niveau recherche, publiés ou non, émanant des établissements d'enseignement et de recherche français ou étrangers, des laboratoires publics ou privés. 
Association of surface dielectric barrier discharge and photocatalysis in continuous reactor at pilot scale: butyraldehyde oxidation, by-products identification and ozone valorization

\author{
GHARIB-ABOU GHAIDA Sara, ASSADI Aymen Amine *, COSTA Guillerme, BOUZAZA \\ Abdelkrim, WOLBERT Dominique \\ Laboratoire Sciences Chimiques de Rennes - équipe Chimie et Ingénierie des Procédés, UMR 6226 \\ CNRS, ENSCR -11, allée de Beaulieu, CS 508307-35708 Rennes, France. \\ * Corresponding author. Tel.: +33 2 23238092; fax: +33 223238120. \\ E-mail address: Aymen.assadi@ensc-rennes.fr (A. ASSADI).
}

\begin{abstract}
Coupling nonthermal plasma with other processes has been studied over the past few years and promising results were obtained concerning VOCs removal for atmospheric pollution control. In this work, butyraldehyde (BUTY) removal by a dielectric barrier discharge (DBD) plasma coupled with different (photo) catalysts based on $\mathrm{TiO}_{2}$ and $\mathrm{MnO}_{2}$ was studied. DBD plasma system and an immobilized $\mathrm{TiO}_{2}$ and $\mathrm{MnO}_{2}$ at different percentages are continually and sequentially combined in order to decompose residual ozone. Indeed, different ways of combination are listed. Effects of relative humidity and initial BUTY concentration on its conversion rate and the distribution of byproducts were examined and discussed. Results with pilot scale showed that combination of plasma and photocatalysis led to an enhancement of BUTY abatement compared to the separate systems. When $100 \%$ of $\mathrm{MnO}_{2}$ catalyst was placed in the post discharge zone, the performance of sequential $\mathrm{DBD} / \mathrm{MnO}_{2}$ combined system is improved in terms of decomposition and conversion rate of the pollutant. In the same way, $\mathrm{CO}$ was reduced and $\mathrm{CO}_{2}$ selectivity was significantly improved when compared to the DBD plasma alone. Intermediate byproducts were identified and BUTY removal pathways are suggested.
\end{abstract}

\title{
Keywords
}

Pilot scale, Sequential coupling processes, DBD plasma, photocatalysis, $\mathrm{TiO}_{2} / \mathrm{MnO}_{2}$ Catalysis. 


\section{Introduction}

Volatile organic compounds (VOCs) constitute one of the most important family of chemicals involved in atmospheric pollution, causing damage to environment and human health [1-3], and need, consequently, to be eliminated. Nevertheless, gas effluents containing low VOCs concentrations are not efficiently treated by conventional industrial processes, for which high power is usually required (i.e. thermal oxidation or catalytic oxidation) [4]. Thus, alternative solutions were investigated over the years, among which nonthermal plasma (NTP) is proved to be an effective technology for the treatment of such effluents with low concentrations particularly $[4,5]$. Dielectric barrier discharge (DBD) is commonly used to create NTP, by applying electrical energy between the two electrodes of the reactor, where at least one of which is covered with dielectric material [6], in order to create high energy electrons (1-10 eV) [5], under moderate conditions (i.e. room temperature and atmospheric pressure)[1, 7]. These electrons are more likely to collide with gas molecules other than the pollutants since their concentrations are low. This results in the production of reactive species such as ions, free radicals and excited species able to react with the pollutants and oxidize them into less harmful compounds $[4,8,9]$. However, debate is still widely open concerning the merits and demerits of this technology. On one hand, nonthermal plasma permits the oxidation of VOCs at relatively low energy cost $[2,4]$, but, on the other hand, it has many disadvantages such as low energy efficiencies, poor selectivity to $\mathrm{CO}_{2}$ even when high conversion rate is reached, and undesirable byproducts formation (e.g. $\mathrm{NO}_{\mathrm{x}}$, ozone, etc.) $[5,9,10]$. Among promising techniques to overcome these limitations, combining plasma NTP with suitable heterogeneous catalysts has been proved to improve the efficiency of VOCs abatement [4], as a synergy effect between NTP and catalytic action is greatly expected [1]. Two configurations of plasma-catalysis are widely used so far: single-stage (also called plasma-driven catalysis PDC or in-plasma catalysis IPC), where catalysts are placed directly in the discharge zone, and two-stage (plasma-enhanced catalysis PEC or post-plasma catalysis PPC), where catalysts are placed downstream the reactor $[4,11]$.

The aim of the present work is to study the decomposition of butyraldehyde at pilot scale using surface dielectric barrier discharge (SDBD) and different (photo) catalysts made of titanium dioxide $\left(\mathrm{TiO}_{2}\right)$, manganese dioxide $\left(\mathrm{MnO}_{2}\right)$, and a mixture of both, in order to determine their catalytic efficiency when coupled with plasma NTP. Moreover, the novelty of this study is the investigation of different configurations in order to optimize and valorize the 
1 residual ozone. Finally, butyraldehyde reaction by-products are identified and a reactional

2 pathway is suggested.

\section{Material and methods}

\subsection{Pilot-scale reactor}

The reactor consists of a glass chamber (length $\mathrm{L}=1000 \mathrm{~mm}$, width $\mathrm{l}=135 \mathrm{~mm}$ and height $\mathrm{H}$ $=135 \mathrm{~mm}$ ), inside of which two glass plates acting as the dielectric media hold, on the inner side, the catalytic media and high voltage grids (stainless steel, rectangular shaped and $2 \mathrm{~mm}$ thickness) and on the outer side, a copper plate forming the outer electrode (1 mm thick and $800 \mathrm{~mm}$ in length). The electrodes are connected to a generator and an amplifier. A coil of capacitors with a total capacity of $2.5 \mathrm{nF}$ is placed between the copper electrode and the connection to ground in order to collect the charges created in the reactor. These two plates are placed one opposite the other at an adjustable distance (Figure 1).

To generate the plasma, high voltage is applied to the reactor. The applied voltage is generated by a generator (BFi OPTILAS) as a sinusoidal waveform up to $10 \mathrm{~V}$ and then amplified by an amplifier (TREK 30/40) to achieve $30 \mathrm{kV}$. The DBD plasma is obtained by subjecting the electrodes to a sinusoidal high voltage ranging from 0 to $30 \mathrm{kV}$ at a frequency of 50 to $200 \mathrm{~Hz}$. The applied voltage $\left(\mathrm{U}_{\text {app }}\right)$ and the voltage across the capacitors $\left(\mathrm{U}_{\mathrm{m}}\right)$ are measured by two probes Optilas connected to a digital oscilloscope (Lecroy wave Surfer 24 Xs $200 \mathrm{MHz}$ ).

Figure 1. Sectional drawing and Schema of NTP coupled with catalysis in planar reactor.

The reactor can be used also as a photocatalytic reactor and as a plasma DBD-photocatalytic reactor. Eight lamps (Philips PL-S 9W / 10 / 4P) continuously emitting between 300 and 460 $\mathrm{nm}$ with a maximum at $365 \mathrm{~nm}$ are placed equidistant from each other in the inter-plate space. The photocatalytic medium is interposed between the stainless steel grid electrode and the dielectric barrier in the plasma active area. It should be noted that the plasma does not activate the photocatalyst in the reactor. The UV lamps arranged in the reactor, permit the activation 
1 of the photocatalyst. Two configurations (continuous and sequential combined system) were 2 tested (Figure 1).

3

4

5

\subsection{Catalysts}

The supported material has been provided by Ahlstrom Research and Services [12]. It is further named Glass Fiber Tissue (GFT) containing colloidal silica, a variable percentage of titanium dioxide and manganese dioxide nanoparticles and inorganic fibers. In fact, titanium dioxide or manganese dioxides have been deposited on inorganic fibers by impregnation using an industrial-size press (Figure 2). A dry mixture of $50 \mathrm{wt} \%$ colloidal silica and different $\mathrm{wt} \%$ of titanium dioxide nanoparticles (PC500 Millennium) and manganese dioxide is suspended in pure water. In order to ensure the deposition of $13 \mathrm{~g} / \mathrm{m}^{2}$ of dry $\mathrm{TiO}_{2}$ and/or $\mathrm{MnO}_{2}$ on fiber support, the suspension is composed of $40 \%$ of dry powder and $60 \%$ of pure water. PC500 $\mathrm{TiO} 2$ nanoparticles are $5-10 \mathrm{~nm}$ in diameter and are of pure anatase form. The specific area of $\mathrm{TiO}_{2}$ nanoparticles is $300 \mathrm{~m}^{2} / \mathrm{g}$. The specific area of $\mathrm{MnO}_{2}$ nanoparticles is $377 \mathrm{~m}^{2} / \mathrm{g}$. The coating process consists in impregnating fibers using industrial size press. The press is employed to impregnate fibers with the suspension; then, they are dried (Figure 2). Material preparation has been performed by Ahlstrom Research and Services.

\section{Figure 2. Diagram of the impregnation technique for GFT synthesis "size press"}

Three catalysts media were produced: GFT with $100 \% \mathrm{TiO}_{2}$, GFT with $100 \% \mathrm{MnO}_{2}$ and GFT with $25 \% \mathrm{MnO}_{2}+75 \% \mathrm{TiO}_{2}$.

\subsection{Polluted air flow generation}

Dry air flow is obtained by an air compressing system.

Butyraldehyde, in liquid state, is directly injected in the flow through a syringe/pump system and the pollutant feed is done continuously through a septum. A heating tape is wrapped around the pipe at the injection zone to ensure good evaporation of the pollutant. Homogenization of the air/pollutant mixture is ensured by a static mixer placed between the syringe/pump system and the reactor. The experiment is carried out at room temperature and 
atmospheric pressure. The temperature and relative humidity are measured by a TESTO sensor.

The main air flow can be generated by the internal network of compressed air when dry air is needed (5\% relative humidity) or by using ambient air when working at a higher flow rate. The compressed air network enables moisture to be controlled by varying the flow in a packed air-water countercurrent column. Thus, it is possible to obtain a range of relative humidity (RH) from 5 to $90 \%$. The entering air flow is measured in real time by a mass flow meter (Bronkhorst In-Flow) calibrated normal cubic meter per hour on the range $0-20 \mathrm{Nm}^{3} \cdot \mathrm{h}^{-1}$.

\subsection{Pollutant and by-products analysis}

The pollutant analysis can only start once the air flow in the reactor reaches equilibrium. In other words, a certain time is required after the pollutant is injected in the air flow crossing the reactor, so that its concentration stabilizes. Once the outlet concentration is stabilized and the catalyst is loaded, plasma DBD is generated and oxidation begins. At this point, samples for pollutant analysis can be taken. Two openings with septum permit taking gas samples at the entrance and exit of the reactor. Analysis of butyraldehyde is performed using a gas chromatography coupled to a Fisons flame ionization detector (GC-FID). A column Chrompact FFAP-CB (25m in length and $0.32 \mathrm{~mm}$ outer diameter) corresponding to the volatile fatty acids is used. Nitrogen is the carrier gas and constitutes the mobile phase. All injections are done manually with a syringe of $1 \mathrm{ml}$ and were repeated at least three times.

The byproducts generated during the DBD plasma oxidation of butyraldehyde are identified and evaluated by Gas Chromatograph-Mass spectrometer (GC-MS) (Perkin Elmer Clarus 500) equipped with an infrared (IR) detector. The temperature conditions in the oven, the injection chamber and the detector are, respectively, 100,120 and $200^{\circ} \mathrm{C}$. Due to their low concentrations, byproducts are concentrated in a Carbotrap $(25 \mathrm{ml})$ then removed by thermal desorption unit coupled with GC-MS [13].

\section{5. $\mathrm{CO}_{2}, \mathrm{CO}$ and $\mathrm{O}_{3}$ analysis}

$\mathrm{CO}_{2}$ outlet concentrations are measured by a Fourier Transform Infrared (FTIR) spectrophotometer brand Environment SA (Cosma Beryl ${ }^{\circledR}$ reference 100, Cosma ${ }^{\circledR}$ Igny, France). The measurement accuracy is about 5\%[13]. CO outlet concentrations are measured 
1 by a $\mathrm{NO} / \mathrm{CO} \_\mathrm{ZRE}$ gas analyzer. $\mathrm{CO}_{2}$ and $\mathrm{CO}$ selectivity's are calculated according to the 2 following equations:

3

4

5

6

7

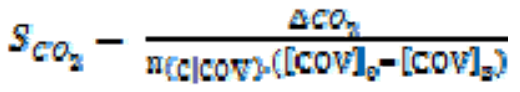

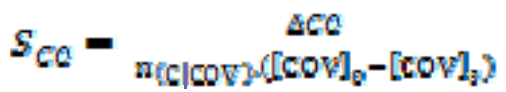

where $[\mathrm{COV}]_{0}$ and $[\mathrm{COV}]_{\mathrm{s}}$ are the inlet and outlet concentrations of BUTY respectively (ppmv), $\mathrm{n}_{(\mathrm{C} \mid \mathrm{COV})}$ is the number of the stoichiometric coefficient of the removal reaction. In our case $n$ is equal to 4 .

A standard iodometric titration method is used to estimate the concentration of the ozone formed during oxidation reactions by DBD plasma. Thus, at the reactor exit, a constant air flow of $285{\mathrm{~L} . \mathrm{h}^{-1}}^{-1}$ s bubbled in a potassium iodide (KI) solution at $10^{-2} \mathrm{M}$. $\mathrm{I}^{-}$is oxidized into $\mathrm{I}_{2}$ and thus gives a yellow solution. After, a standard iodometric titration method is used to estimate the downstream ozone formation [13].

\section{Results and discussion}

To follow the degradation of butyraldehyde, two parameters were selected: Conversion rate (CR), which was calculated as follow:

$$
\operatorname{CR}(\%)=\frac{c_{\text {in }}-c_{\text {gut }}}{c_{\text {in }}} \times 100
$$

Elimination Capacity (EC) which was estimated according to the equation:

$$
\mathrm{EC}(\mathrm{mg} / \mathrm{g} \cdot \mathrm{h})=\frac{\varsigma_{\mathrm{in}}-\varsigma_{\mathrm{gut}}}{m_{\mathrm{Ti} 0_{\mathrm{I}}}} \times \mathrm{Q}_{\mathrm{sin}}
$$

Where $\mathrm{C}_{\text {in }}$ and $\mathrm{C}_{\text {out }}$ are the inlet and the outlet BUTY concentrations $\left(\mathrm{mg} \cdot \mathrm{m}^{-3}\right.$ ), respectively. $\mathrm{m}_{\mathrm{TiO} 2}$ is the amount of catalyst deposited on glass fiber tissue.

Depending on the need, one or the other will be used for expressing the results obtained during experiments.

\subsection{Butyraldehyde oxidation: GFT with $100 \%$ of $\mathrm{TiO}_{2}$}


1 We started our investigations by studying BUTY elimination by photocatalysis $\left(\mathrm{UV} / \mathrm{TiO}_{2}\right)$

2 and plasma DBD separately, then by coupling both technologies.

3 Figure (3) shows variation of the elimination capacity (EC) of butyraldehyde by

4 photocatalysis versus air flow rate and BUTY inlet concentration. On figure (4) the influence

5 of relative humidity (RH) is represented. It can be noted that butyraldehyde EC increases

6 when air flow rate and inlet pollutant concentration are increased. Knowing that

7 photocatalysis reaction is often assimilated to a pseudo-first order reaction, this means that a

8 greater flow of pollutant (due to the increased air flow rate or inlet concentration) naturally

9 induces an increase in the degradation kinetics [13-15]. Of course, for a constant amount of

10 catalyst, the percentage of degradation and mineralization will decrease when these operating

11 parameters increase.

Figure 3. Variation of EC with inlet concentration at different flow rates $\left(\mathrm{SE}=17 \mathrm{~J} . \mathrm{L}^{-1}\right.$, $\mathrm{T}=20^{\circ} \mathrm{C}, \mathrm{RH}=5 \%, \mathrm{I}=20 \mathrm{~W} \cdot \mathrm{m}^{-2}$ )

The EC also varies with relative humidity and is optimal when approaching $25-30 \%$ for all pollutant inlet concentrations tested. However, it is more visible for high inlet concentrations (120 and $160 \mathrm{mg} / \mathrm{Nm}^{3}$ ). When $\mathrm{RH}$ exceeds a certain threshold, butyraldehyde EC decreases remarkably.

In fact, RH has two opposite effects in photocatalysis alone. Initially, the presence of water molecules in the air improves the EC of BUTY due to the dissociation of $\mathrm{H}_{2} \mathrm{O}$, forming new reactive species $\left(\mathrm{H}^{\bullet}\right.$ and $\left.\mathrm{HO}^{\bullet}\right)$. Secondly, when $\mathrm{RH}$ rises too much, a competition effect between the pollutant and water molecules for the active sites on the photocatalyst surface predominates, diminishing consequently EC $[12,16]$.

Figure 4. Variation of EC with RH at different inlet concentrations (SE $=17$ J.L ${ }^{-1}$, $Q_{\text {air }}=$

$$
2 \mathbf{m}^{3} \cdot \mathrm{h}^{-1}, \mathrm{I}=\mathbf{2 0 W} \cdot \mathrm{m}^{-2} \text { ) }
$$

Figure 5 shows BUTY behavior when it is oxidized by plasma DBD alone or by coupling $\left(\mathrm{UV} / \mathrm{TiO}_{2} / \mathrm{DBD}\right)$ in function of injected energy. 
1 BUTY abatement is significantly better when coupling processes than with Photocatalysis or

2 DBD alone, whatever the injected energy, air flow rate or inlet pollutant concentration are.

3 With DBD alone, we note that BUTY conversion rate increases with the increase of injected

Figure 5. Variation of conversion rate with relative humidity vs. different processes using GFT with $100 \% \mathrm{TiO}_{2}\left(Q_{\text {air }}=2 \mathrm{Nm}^{3} \cdot \mathrm{h}^{-1},\left[\mathrm{C}_{4} \mathrm{H}_{8} \mathrm{O}\right]=80 \mathrm{mg} \cdot \mathrm{Nm}^{-3}, \mathrm{E}_{\text {inj }}=17 \mathrm{~J} . \mathrm{L}^{-1}, \mathrm{RH}\right.$ $=5-7 \%, \mathrm{~T}=18-20^{\circ} \mathrm{C}$ )

Clearly, BUTY removal is from 3 to $10 \%$ higher when coupling processes than using photocatalysis or plasma separately. From the graphic above (Figure 5), the CR increases and then drops. In fact, when $\mathrm{RH}$ increases, the competitive effect towards the active sites of water and the consumption of actives species of plasma becomes predominant and thus the CR decreases. We note an optimum at around $30 \%$ of RH. In our case the values of CR are $29.97 \%, 34.34 \%$ and $70.76 \%$ with photocatalysis, DBD and coupling respectively. In addition, it must be pointed that coupling photocatalysis with DBD helps maintaining a relatively high $\mathrm{CR}$ of butyraldehyde. For example, for $\mathrm{RH}=80 \%$, coupling insures a $\mathrm{CR}$ equal to $\sim 63 \%$, while CR with photocatalysis and DBD does not exceed 23.05 and $27.47 \%$ respectively.

This synergistic effect is observed under different experimental conditions. These observations are similar to those obtained by several groups of researchers $[14,15,17,19]$.

\subsection{Intermediates identification}


2 We wanted to follow closely the degradation of butyraldehyde, so we decided to identify the

3 degradation by-products by gas chromatography coupled to mass spectrometry (GC-MS).

$4 \quad$ Three samples were taken for butyraldehyde after each treatment process. Analyses of outlet

\section{Figure 6. By-products identified by GC-MS following butyraldehyde oxidation by the} combined system

Compounds present in the outlet air were detected by GC-MS. Regarding butyraldehyde as pure substance and its oxidation by combined system; the detected degradation by-products were acetone (1), ethyl acetate (2), acetic acid (3), propionic acid (4) and butyric acid (5). Butyraldehyde is also detected at the exit of the reactor at $32.6 \mathrm{ppm}$. The same intermediates as in combined system were detected when plasma was used alone.

These results are comparable to those obtained by Ye et al. (2006) [19], where they were able to detect, after treatment by photocatalysis, the presence of acetic, propionic, and butyric acids, but in liquid phase. They detected other compounds in gas phase: propionaldehyde and acetaldehyde.

Since different oxidation mechanisms occur when plasma treatment is on, we suggest the following reactional mechanism for butyraldehyde degradation (Figure 7), where ethyl acetate and butyric acid derive directly from butyraldehyde and could dissociate into acetic acid, acetone and propionic acid (all detected with GC-MS), respectively, according to the represented reaction pathway. 
Figure 7. Suggested reaction scheme of BUTY oxidation by combination of GFT with $100 \% \mathrm{TiO}_{2}$ and DBD

\section{3. $\quad \mathrm{CO}$ and $\mathrm{CO}_{2}$ selectivity, and ozone formation}

Figure 8 shows that photocatalysis is the most selective to $\mathrm{CO}_{2}$ among the three processes tested. We also note that introducing the photocatalyst $\left(\mathrm{TiO}_{2}\right)$ in the plasma can improve the selectivity to $\mathrm{CO}_{2}$. The production of $\mathrm{CO}$ is generally low and its concentration rarely exceed $10 \%$. As for ozone, huge amounts are produced with plasma alone and with coupled processes.

However, we also notice that for the same injected energy $\left(12.8 \mathrm{~J} . \mathrm{L}^{-1}\right)$, coupling ensures a higher BUTY conversion rate while decreasing generated $\mathrm{O}_{3}$ quantity. This behavior could be explained by the fact that $\mathrm{O}_{3}$ is decomposed in the presence of external UV light to the planar reactor [16].

\section{Figure 8. $\mathrm{CO}_{2}$ and $\mathrm{CO}$ selectivity's, and removal rate of oxidized butyraldehyde by} photocatalysis, plasma DBD and combined system $\left(Q_{\text {air }}=2 \mathrm{Nm}^{3} \cdot \mathrm{h}^{-1},\left[\mathrm{C}_{4} \mathrm{H}_{8} \mathrm{O}\right]=80\right.$

$$
\text { mg.Nm } \left.{ }^{-3}, E_{\text {inj }}=12.8{\mathrm{~J} . \mathrm{L}^{-1}}, \mathrm{RH}=5-7 \%, \mathrm{~T}=18-20^{\circ} \mathrm{C}\right) \text {. }
$$

\section{Effect of adding $\mathrm{MnO}_{2}$ catalysis: continuous and sequential configurations}

Ozone is known to be an inevitable by-product of plasma. Interactions between highly energetic electrons and molecular oxygen produce atomic oxygen. This latter interacts then with molecular oxygen in the bulk gas to form ozone as follows [20]:

$$
\begin{aligned}
& \mathrm{e}^{-}+\mathrm{O}_{2} \rightarrow \mathrm{e}^{-}+{ }^{\cdot} \mathrm{O}+{ }^{\cdot} \mathrm{O} \\
& \mathrm{O}+\mathrm{O}_{2}+\mathrm{M} \rightarrow \mathrm{O}_{3}+\mathrm{M}
\end{aligned}
$$

where $\mathrm{M}$ is a third body for discharging excess energy of the reaction, which can be $\mathrm{N}_{2}, \mathrm{O}_{2}$ or a surface. 
1 Although coupling DBD/photocatalysis processes reduces ozone generation like we discussed

2 previously, the concentrations emitted remain high (about some dozens of ppm) and dangerously threatening human health. In fact, this oxidizing gas, even at relatively low concentrations, is capable of damaging bronchiolar and alveolar cells and interacting with some receptors and some protein molecules, lipids or certain enzymes [21]. Short-term inhalation of ozone at concentrations that occur in urban environment causes acute conduit artery vasoconstriction [22]. Due to its dangerous effects, it would be more benefic to minimize its generation to avoid forming intermediate products that may be more toxic than the original pollutant.

A second aim of the present study is, consequently, to minimize as much as possible and valorize ozone production by implying it in the decomposition of pollutants. Thus, a series of experiments was carried out under plasma, by testing different catalysts compositions and their positions in the reactor.

\subsection{Continuous configurations (plasma and catalysis in-situ)}

In our tentative for reducing ozone emissions by the DBD process, a series of BUTY oxidation experiments was carried out by testing different catalyst media. Three media was tested, $\mathrm{TiO}_{2}$ as a photocatalyst for VOCs removal [12-15, 17, 24-26], $\mathrm{MnO}_{2}$ for ozone degradation [26] and the combination of $\mathrm{TiO}_{2} / \mathrm{MnO}_{2}$ to enhance catalytic activity [27].

Figure 9 shows the influence of each catalyst mentioned above in butyraldehyde removal and ozone formation.

Figure 9. Effect of catalyst composition on BUTY conversion rate and the amount of formed ozone by plasma-catalytic monobloc system (IPC) $\left(Q_{\text {air }}=4 \mathrm{Nm}^{-3} \cdot \mathrm{h}^{-1},\left[\mathrm{C}_{4} \mathrm{H}_{8} \mathrm{O}\right]=\right.$ $\left.50 \mathrm{mg} . \mathrm{Nm}^{-3}, \mathrm{E}_{\mathrm{inj}}=12.96{\mathrm{~J} . \mathrm{L}^{-1}}, \mathrm{RH}=5-7 \%, \mathrm{~T}=18-20^{\circ} \mathrm{C}\right)$ 
1 We note that $\mathrm{MnO}_{2}$ alone is very reactive when activated by DBD alone. Compared to $\mathrm{TiO}_{2}$ alone or DBD alone, it improves butyraldehyde abatement by a factor of 1.9, but surprisingly, it increases also ozone production by a factor of 2.1. Probably this is due to the fact that the presence of $\mathrm{MnO}_{2}$ in the discharge zone may affect the discharge characteristics: an increase in the production of active species [28] could have helped reducing the amount of consumed ozone for butyraldehyde oxidation. Indeed, Ozone is created from atomic oxygen in a reaction to three bodies according to reaction (b). When introducing the fibers into the plasma zone, it expands the solid surface in contact with the plasma. This increases the probability that oxygen enhances with third body for producing of ozone. Presumably oxygen atoms are adsorbed on the surface and react with $\mathrm{O}_{2}$. Accordingly, the ozone concentration increases [30-32].

When hybridized with $\mathrm{TiO}_{2}$, it reduces the generation of ozone by a factor of 7.2 , but on the other hand, it decreases by a factor of 1.7 butyraldehyde removal compared to $\mathrm{MnO}_{2}$ alone. In a first conclusion, we can note that hybrid catalyst seems to have the highest ozone removal rate. However, since optimization of the reactor performance is our main objective, it would be idealistic if we can achieve a highest removal rate with the lowest ozone generation. The combined catalyst $\left(75 \% \mathrm{TiO}_{2}+25 \% \mathrm{MnO}_{2}\right)$ permits to have the lowest ozone outlet concentration when placed in the discharge zone, but it decreases pollutant removal rate by almost the half. Thus, further investigation was conducted in order to study the reasons behind this decrease in BUTY conversion rate. Experiments with $\mathrm{UV} / \mathrm{TiO}_{2}, \mathrm{UV} / \mathrm{MnO}_{2}$ and $\mathrm{UV} / \mathrm{TiO}_{2} / \mathrm{MnO}_{2}$ were performed (Figure 10). CR of butyraldehyde was compared to that obtained with $\mathrm{DBD} / \mathrm{TiO}_{2}$-and/or- $\mathrm{MnO}_{2}$ (Figure 9).

\section{Figure 10. Comparison of the photocatalytic performance of different media for BUTY oxidation $\left(Q_{\text {air }}=4 \mathrm{Nm}^{-3} \cdot \mathrm{h}^{-1},\left[\mathrm{C}_{4} \mathrm{H}_{8} \mathrm{O}\right]=50 \mathrm{mg} \cdot \mathrm{Nm}^{-3}, \mathrm{RH}=5-7 \%, \mathrm{~T}=18-20^{\circ} \mathrm{C}\right)$}

Based on the obtained results, we note that the presence of $\mathrm{MnO}_{2}$ seems to completely inhibit the photocatalytic activity of $\mathrm{TiO}_{2}$. A clear explanation for this finding has not been established yet. However, some researchers working on the photocatalytic activity of $\mathrm{TiO}_{2}$ combined with $\mathrm{MnO}_{2}$ in liquid phase have found similar results [27, 29]. They admit that the photocatalytic activity of $\mathrm{TiO}_{2}$ under UV irradiation decreases when its surface is modified by $\mathrm{MnO}_{2}$ particles. These particles affect $\mathrm{O}_{2}$ reduction. This leads to a decrease of UV radiations 
and therefore their absorption by $\mathrm{TiO}_{2}$ [30]. Heterojunctions formation between $\mathrm{MnO}_{2}$ and $\mathrm{TiO}_{2}$ particles seems responsible for altering the chemical status of $\mathrm{Ti}^{4+}$ and $\mathrm{O}^{2-}$ sites in the crystalline phase of $\mathrm{TiO}_{2}$ [29]. This poisoning effect of $\mathrm{TiO}_{2}$ by $\mathrm{MnO}_{2}$ might be present in the gas phase and could explain our results.

\subsection{Sequential combinations}

Since $\mathrm{MnO}_{2}$ placed in the discharge zone was not efficient for reducing ozone generation by DBD process, a second series of experiments was carried out, where $\mathrm{MnO}_{2}$ is placed downstream of the discharge zone. Reactor was in PPC configuration. Samples were taken from the middle zone (Part I) and the exit of the reactor (Part II), i.e. before and after contact with catalyst surface. Results obtained showed a huge reduction in ozone emissions along with improvement in butyraldehyde CR (Figure 11). This observation suggests that ozone produced in the discharge zone is dissociated on $\mathrm{MnO}_{2}$ surface, generating more reactive species contributing to BUTY oxidation [31].

Relative humidity, when increased, enhances ozone reduction significantly, but not BUTY oxidation, CR decreases slightly (Figure 11). However, this increase in ozone reduction is not clearly seen when inlet air flow rate is increased from 2 to $4 \mathrm{Nm}^{3} \cdot \mathrm{h}^{-1}$ (results not shown). This could be due to the short residence time of butyraldehyde in the reactor. Thus, working with a packed-bed of $\mathrm{MnO}_{2}$ beads, instead of GFT, which could provide an increased contact of BUTY with the catalyst surface, might be a better alternative.

Figure 5. Effect of RH on BUTY conversion rate and ozone formation in PPC for the same BUTY inlet concentration ( Qair = 2 Nm3.h-1, [C4H8O] = 50 mg.Nm-3, Einj = 12.96 J.L-1,T $=18-20^{\circ} \mathrm{C}$ ) On the left:, $\mathrm{RH}=5-7 \%$, On the right: $\mathrm{RH}=55 \%$.

\section{Conclusions}


1 As a conclusion, we can note firstly that plasma/photocatalysis combination with UV light

2 provides better performance concerning Buty degradation. Secondly, UV/DBD/TiO 2

3 configuration results in a slight ozone reduction, an increase in $\mathrm{CO}_{2}$ selectivity and a

4 synergistic effect was observed.

5 Influence of $\mathrm{MnO}_{2}$ and $\mathrm{MnO}_{2} / \mathrm{TiO}_{2}$ media was also studied. When using $\mathrm{DBD} / \mathrm{MnO}_{2}$

6 combination with no external UV light, a better butyraldehyde oxidation in IPC configuration

7 was obtained but huge amounts of ozone was produced. Under PPC configuration, lower

8 ozone amounts but also lower butyraldehyde decomposition were obtained.

9 It seems that PPC configuration using $\mathrm{MnO}_{2}$ catalyst without external UV light could be the best compromise between good butyraldehyde decomposition and low ozone production. Further optimization of the process is still required in order to obtain the same promising results for higher air flow rates.

\section{Acknowledgments:}

This work is supported by the French National Research Agency (ANR). Alexander Vorontsov (Boreskov Institute of Catalysis, Russia) is gratefully acknowledged for highlighting discussions. 


\section{References:}

[1] J. Karuppiah, E. L. Reddy, P. M. Kumar, B. Ramaraju, R. Karvembu, and C. Subrahmanyam, "Abatement of mixture of volatile organic compounds ( VOCs ) in a catalytic non-thermal plasma reactor," J. Hazard. Mater., vol. 237-238, pp. 283-289, 2012.

[2] H. T. Quoc An, T. Pham Huu, T. Le Van, J. M. Cormier, and a. Khacef, "Application of atmospheric non thermal plasma-catalysis hybrid system for air pollution control: Toluene removal," Catal. Today, vol. 176, no. 1, pp. 474-477, 2011.

[3] C. Subrahmanyam, "Catalytic non-thermal plasma reactor for total oxidation of volatile organic compounds," Indian J. Chem., vol. 48, no. August, pp. 1062-1068, 2009.

[4] J. Jarrige and P. Vervisch, "Plasma-enhanced catalysis of propane and isopropyl alcohol at ambient temperature on a MnO2-based catalyst," Appl. Catal. B Environ., vol. 90 , no. $1-2$, pp. 74-82, 2009.

[5] Y. Guo, D. Ye, K. Chen, J. He, and W. Chen, "Toluene decomposition using a wireplate dielectric barrier discharge reactor with manganese oxide catalyst in situ," vol. 245, pp. 93-100, 2006.

[6] X. Tang, F. Gao, J. Wang, H. Yi, S. Zhao, B. Zhang, Y. Zuo, and Z. Wang, "Comparative Study between Single- and Double-Dielectric Barrier Discharge Reactor for Nitric Oxide Removal,” pp. 6197-6203, 2014. 
2 [7] H. Kim, Y. Teramoto, N. Negishi, and A. Ogata, "nonthermal plasma and catalyst: A review," Catal. Today, 2015.

[8] S. Delagrange, L. Pinard, and J. Tatiboue, "Combination of a non-thermal plasma and a catalyst for toluene removal from air: Manganese based oxide catalysts," vol. 68, pp. 92-98, 2006.

[9] A. Pollution, C. Part, E. Marotta, A. Callea, and M. Rea, "DC Corona Electric Discharges for Air Pollution Control. Part 1. Efficiency and Products of Hydrocarbon Processing," vol. 41, no. 16, pp. 5862-5868, 2007.

[10] U. Roland, F. Holzer, and F. D. Kopinke, "Combination of non-thermal plasma and heterogeneous catalysis for oxidation of volatile organic compounds: Part 2. Ozone decomposition and deactivation of ??-Al2O3," Appl. Catal. B Environ., vol. 58, no. 34, pp. 217-226, 2005.

[11] G. Xiao, W. Xu, R. Wu, M. Ni, C. Du, X. Gao, Z. Luo, and K. Cen, Non-thermal plasmas for VOCs abatement, vol. 34, no. 5. 2014.

[12] J. Palau, a. a. Assadi, J. M. Penya-roja, a. Bouzaza, D. Wolbert, and V. MartínezSoria, "Isovaleraldehyde degradation using UV photocatalytic and dielectric barrier discharge reactors, and their combinations," J. Photochem. Photobiol. A Chem., vol. 299, pp. 110-117, 2015.

[13] A. A. Assadi, A. Bouzaza, M. Lemasle, and D. Wolbert, "Removal of trimethylamine and isovaleric acid from gas streams in a continuous flow surface discharge plasma reactor," Chem. Eng. Res. Des., pp. 1-12, 2014.

[14] A. A. Assadi, A. Bouzaza, and D. Wolbert, "Photocatalytic oxidation of trimethylamine and isovaleraldehyde in an annular reactor: Influence of the mass transfer and the relative humidity," J. Photochem. Photobiol. A Chem., vol. 236, pp. 61-69, 2012.

[15] A. A. Assadi, J. Palau, A. Bouzaza, J. Penya-Roja, V. Martinez-Soriac, and D. Wolbert, "Abatement of 3-methylbutanal and trimethylamine with combined plasma and photocatalysis in a continuous planar reactor," J. Photochem. Photobiol. A Chem., vol. 282, pp. 1-8, 2014.

[16] A. A. Assadi, A. Bouzaza, S. Merabet, and D. Wolbert, "Modeling and simulation of VOCs removal by nonthermal plasma discharge with photocatalysis in a continuous reactor: Synergetic effect and mass transfer," Chem. Eng. J., vol. 258, pp. 119-127, 2014. 
[17] Y. Guo, X. Liao, J. He, W. Ou, and D. Ye, "Effect of manganese oxide catalyst on the dielectric barrier discharge decomposition of toluene," Catal. Today, vol. 153, no. 3-4, pp. 176-183, 2010.

[18] A. V Vorontsov, M. N. Lyulyukin, and A. S. Besov, "Abatement of air pollutants in combined plasma and photocatalytic systems," 2011.

[19] X. Ye, D. Chen, J. Gossage, and K. Li, "Photocatalytic oxidation of aldehydes: Byproduct identification and reaction pathway," J. Photochem. Photobiol. A Chem., vol. 183 , no. $1-2$, pp. 35-40, 2006.

[20] R. Atkinson, D. L. Baulch, R. a. Cox, J. N. Crowley, R. F. Hampson, R. G. Hynes, M. E. Jenkin, M. J. Rossi, J. Troe, and T. J. Wallington, "Evaluated kinetic and photochemical data for atmospheric chemistry: Volume IV \&ndash; gas phase reactions of organic halogen species," Atmos. Chem. Phys. Discuss., vol. 7, no. 6, pp. 16349-17067, 2007.

[21] L. Pascal, "Effets à court terme de la pollution atmosphérique sur la mortalité," Revue Française d'Allergologie, vol. 49, no. 6. pp. 466-476, 2009.

[22] R. D. Brook, J. R. Brook, B. Urch, R. Vincent, S. Rajagopalan, and F. Silverman, "Inhalation of fine particulate air pollution and ozone causes acute arterial vasoconstriction in healthy adults," Circulation, vol. 105, no. 13, pp. 1534-1536, 2002.

[23] A. A. Assadi, A. Bouzaza, C. Vallet, and D. Wolbert, "Use of DBD plasma, photocatalysis, and combined DBD plasma/photocatalysis in a continuous annular reactor for isovaleraldehyde elimination - Synergetic effect and byproducts identification," Chem. Eng. J., vol. 254, pp. 124-132, 2014.

[24] A. A. Assadi, A. Bouzaza, M. Lemasle, and D. Wolbert, "Removal of trimethylamine and isovaleric acid from gas streams in a continuous flow surface discharge plasma reactor," Chem. Eng. Res. Des., vol. 93, no. May, pp. 640-651, 2014.

[25] A. A. Assadi, J. Palau, A. Bouzaza, and D. Wolbert, "Modeling of a continuous photocatalytic reactor for isovaleraldehyde oxidation: Effect of different operating parameters and chemical degradation pathway," Chem. Eng. Res. Des., vol. 91, no. 7, pp. 1307-1316, 2013.

[26] T. Zhu, Y. D. Wan, J. Li, X. W. He, D. Y. Xu, X. Q. Shu, W. J. Liang, and Y. Q. Jin, "Volatile organic compounds decomposition using nonthermal plasma coupled with a combination of catalysts," Int. J. Environ. Sci. Technol., vol. 8, no. 3, pp. 621-630, 2011. 
[27] J. Van Durme, J. Dewulf, W. Sysmans, C. Leys, and H. Van Langenhove, "Efficient toluene abatement in indoor air by a plasma catalytic hybrid system," Appl. Catal. B Environ., vol. 74, no. 1-2, pp. 161-169, 2007.

[28] J. Van Durme, J. Dewulf, C. Leys, and H. Van Langenhove, "Combining non-thermal plasma with heterogeneous catalysis in waste gas treatment: A review," Appl. Catal. B Environ., vol. 78, no. 3-4, pp. 324-333, 2008.

[29] S. Li, Z. Ma, L. Wang, and J. Liu, "Influence of MnO2 on the photocatalytic activity of P-25 TiO2 in the degradation of methyl orange," Sci. China, Ser. B Chem., vol. 51, no. 2, pp. 179-185, 2008.

[30] Q. Jin, H. Arimoto, M. Fujishima, and H. Tada, "Manganese Oxide-Surface Modified Titanium(IV) Dioxide as Environmental Catalyst," Catalysts, vol. 3, no. 2, pp. 444454, Apr. 2013.

[31] F. Thevenet, L. Sivachandiran, O. Guaitella, C. Barakat, and a Rousseau, "Plasmacatalyst coupling for volatile organic compound removal and indoor air treatment: a review," J. Phys. D. Appl. Phys., vol. 47, no. 22, p. 224011, 2014.

[32] K. Allegraud. Décharge à Barrière Diélectrique de Surface : physique et procédé, thèse Ecole polytechnique de Paris, 2008.

(1)

.

7

88

9

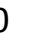


Figures:

Figure 6. Sectional drawing and Schema of NTP coupled with catalysis in planar reactor.

Figure 7. Diagram of the impregnation technique for GFT synthesis "size press"

Figure 8. Variation of EC with inlet concentration at different flow rates $\left(\mathrm{SE}=17 \mathrm{~J} . \mathrm{L}^{-1}, \mathrm{~T}=\right.$ $\left.1420^{\circ} \mathrm{C}, \mathrm{RH}=5 \%, \mathrm{I}=20 \mathrm{~W} \cdot \mathrm{m}^{-2}\right)$.

Figure 9. Variation of EC with RH at different inlet concentrations $\left(\mathrm{SE}=17 \mathrm{~J} \cdot \mathrm{L}^{-1}, \mathrm{Q}_{\text {air }}=2\right.$ $\left.\mathrm{m}^{3} \cdot \mathrm{h}^{-1}, \mathrm{I}=20 \mathrm{~W} \cdot \mathrm{m}^{-2}\right)$.

Figure 5. Variation of conversion rate with relative humidity in function of different processes using GFT with $100 \% \mathrm{TiO}_{2}\left(\mathrm{Q}_{\text {air }}=2 \mathrm{Nm}^{3} \cdot \mathrm{h}^{-1},\left[\mathrm{C}_{4} \mathrm{H}_{8} \mathrm{O}\right]=80 \mathrm{mg} \cdot \mathrm{Nm}^{-3}, \mathrm{E}_{\text {inj }}=17 \mathrm{~J} \cdot \mathrm{L}^{-1}, \mathrm{RH}=5-\right.$ $\left.197 \%, \mathrm{~T}=18-20^{\circ} \mathrm{C}\right)$.

Figure 6. By-products identified by GC-MS following butyraldehyde oxidation by the 21 combined system.

22 Figure 7. Suggested reaction scheme of BUTY oxidation by combination of GFT with 100\% $\mathrm{TiO}_{2}$ and DBD. 
1 Figure 8. $\mathrm{CO}_{2}$ and $\mathrm{CO}$ selectivity's, and removal rate of oxidized butyraldehyde by 2 photocatalysis, plasma DBD and combined system $\left(\mathrm{Q}_{\text {air }}=2 \mathrm{Nm}^{3} \cdot \mathrm{h}^{-1},\left[\mathrm{C}_{4} \mathrm{H}_{8} \mathrm{O}\right]=80 \mathrm{mg} \cdot \mathrm{Nm}^{-3}\right.$, $\left.3 \quad \mathrm{E}_{\mathrm{inj}}=12.8 \mathrm{~J} \cdot \mathrm{L}^{-1}, \mathrm{RH}=5-7 \%, \mathrm{~T}=18-20^{\circ} \mathrm{C}\right)$.

4 Figure 9. Effect of catalyst composition on BUTY conversion rate and the amount of formed 5 ozone by plasma-catalytic monobloc system (IPC) $\left(\mathrm{Q}_{\text {air }}=4 \mathrm{Nm}^{-3} \cdot \mathrm{h}^{-1},\left[\mathrm{C}_{4} \mathrm{H}_{8} \mathrm{O}\right]=50 \mathrm{mg} \cdot \mathrm{Nm}^{-3}\right.$, $\left.6 \quad \mathrm{E}_{\mathrm{inj}}=12.96 \mathrm{~J} . \mathrm{L}^{-1}, \mathrm{RH}=5-7 \%, \mathrm{~T}=18-20^{\circ} \mathrm{C}\right)$.

7 Figure 10. Comparison of the photocatalytic performance of different media for BUTY 8 oxidation $\left(\mathrm{Q}_{\text {air }}=4 \mathrm{Nm}^{-3} \cdot \mathrm{h}^{-1},\left[\mathrm{C}_{4} \mathrm{H}_{8} \mathrm{O}\right]=50 \mathrm{mg} \cdot \mathrm{Nm}^{-3}, \mathrm{RH}=5-7 \%, \mathrm{~T}=18-20^{\circ} \mathrm{C}\right)$

9 Figure 11. Effect of RH on BUTY Conversion rate and ozone formation in PPC for the same BUTY inlet concentration $($ Qair $=2 \mathrm{Nm} 3 . \mathrm{h}-1$, [C4H8O] $=50 \mathrm{mg} . \mathrm{Nm}-3$, Einj $=12.96 \mathrm{~J} . \mathrm{L}-1, \mathrm{~T}$ $11=18-20^{\circ} \mathrm{C}$ ) On the left:, $\mathrm{RH}=5-7 \%$, On the right: $\mathrm{RH}=55 \%$.

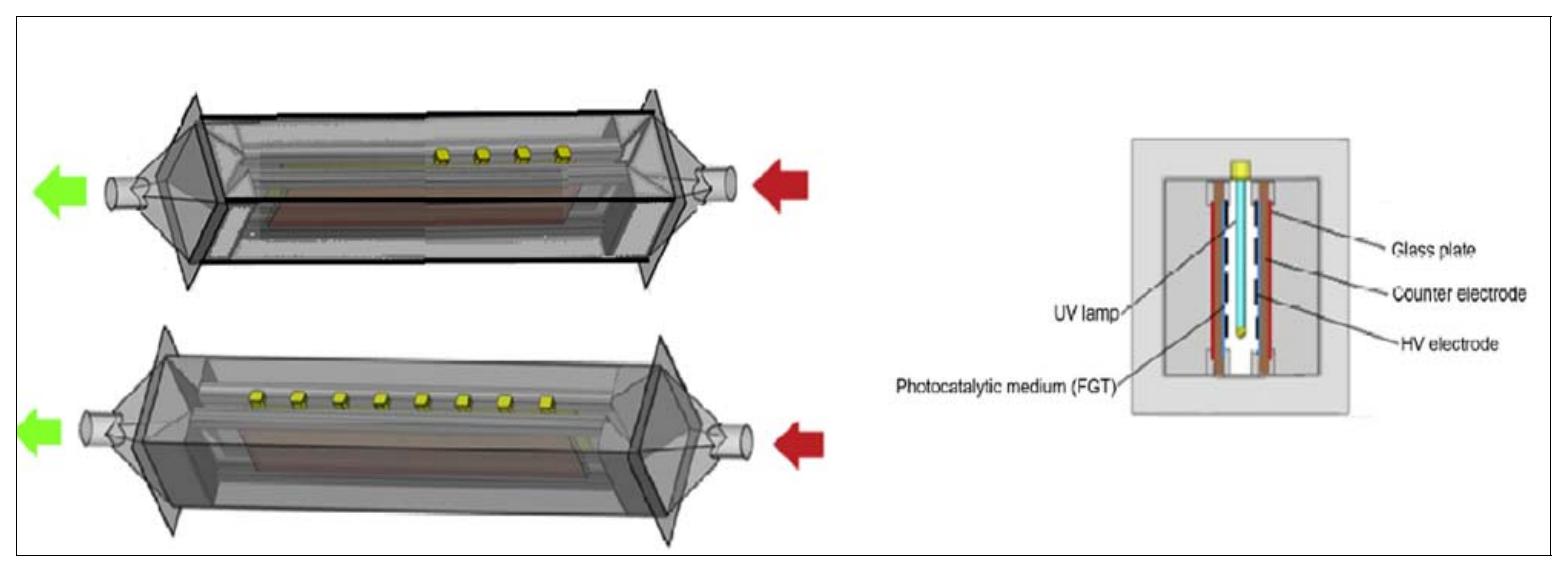




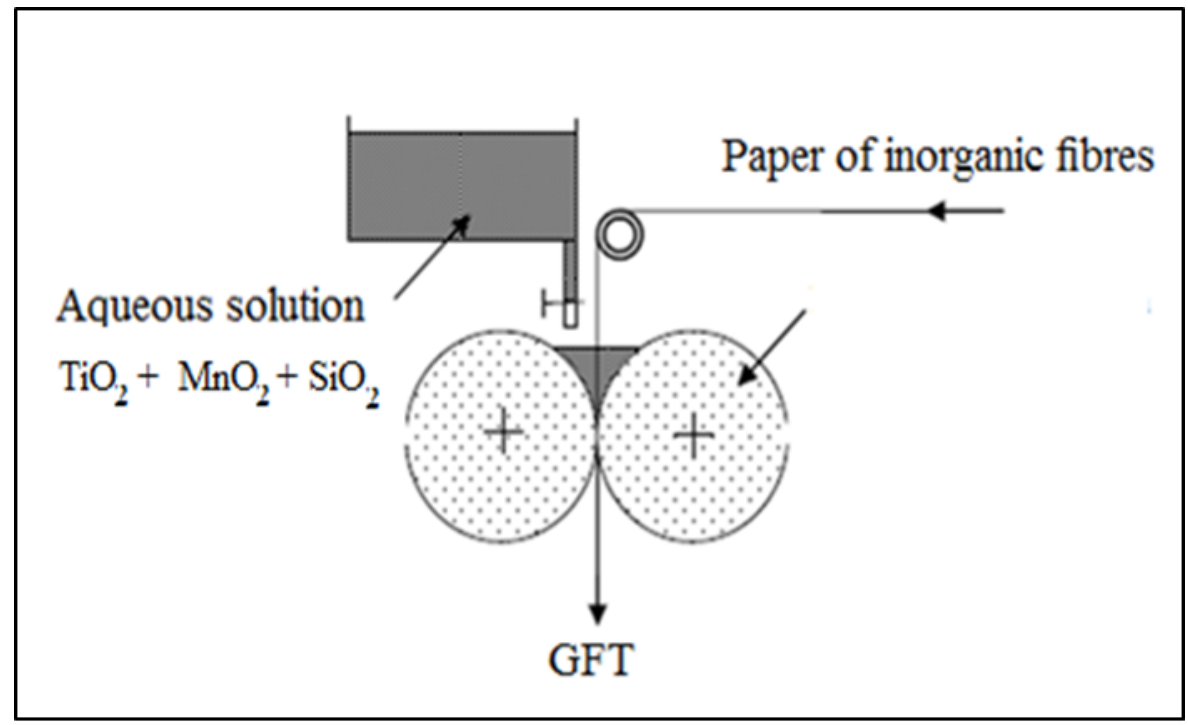

16

Figure 11. Diagram of the impregnation technique for GFT synthesis "size press" 


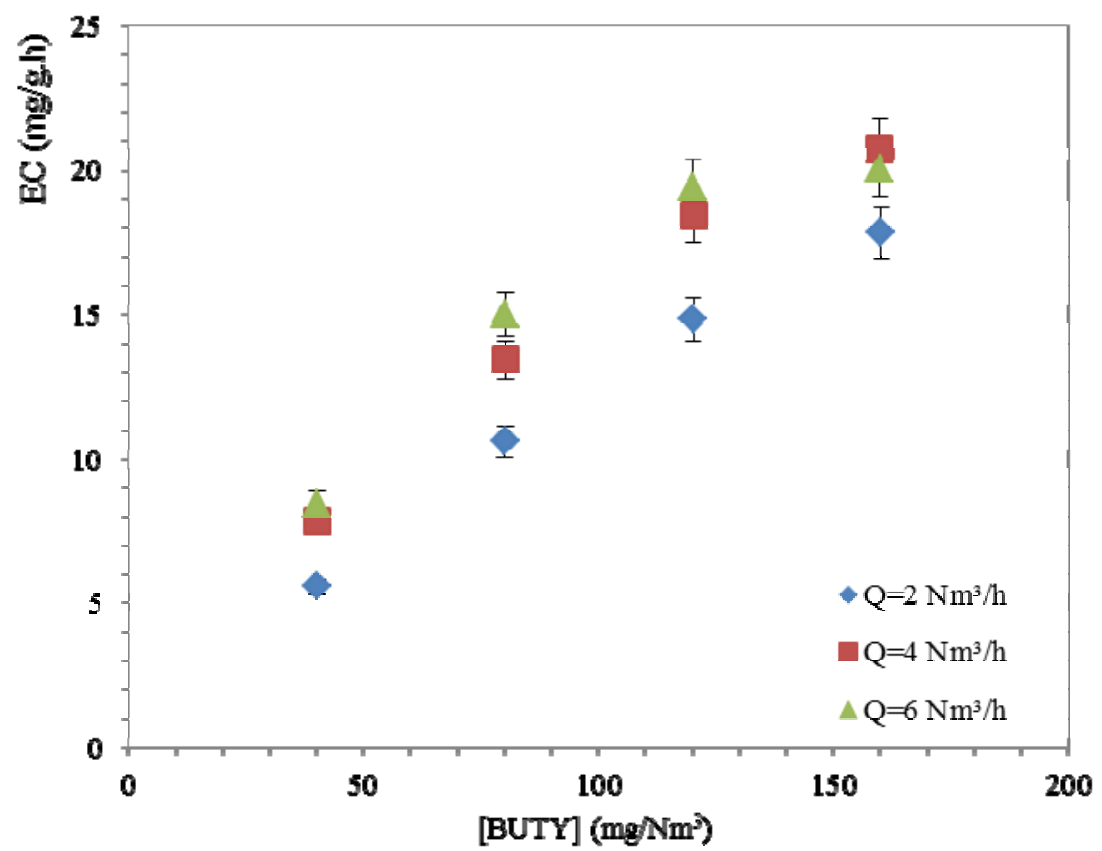

Figure 12. Variation of EC with inlet concentration at different flow rates $\left(\mathrm{SE}=17 \mathrm{JJ}^{-1}, \mathrm{~T}=20^{\circ} \mathrm{C}, \mathrm{RH}=5 \%, \mathrm{I}=20\right.$ 18 W.m $\left.{ }^{-2}\right)$. 


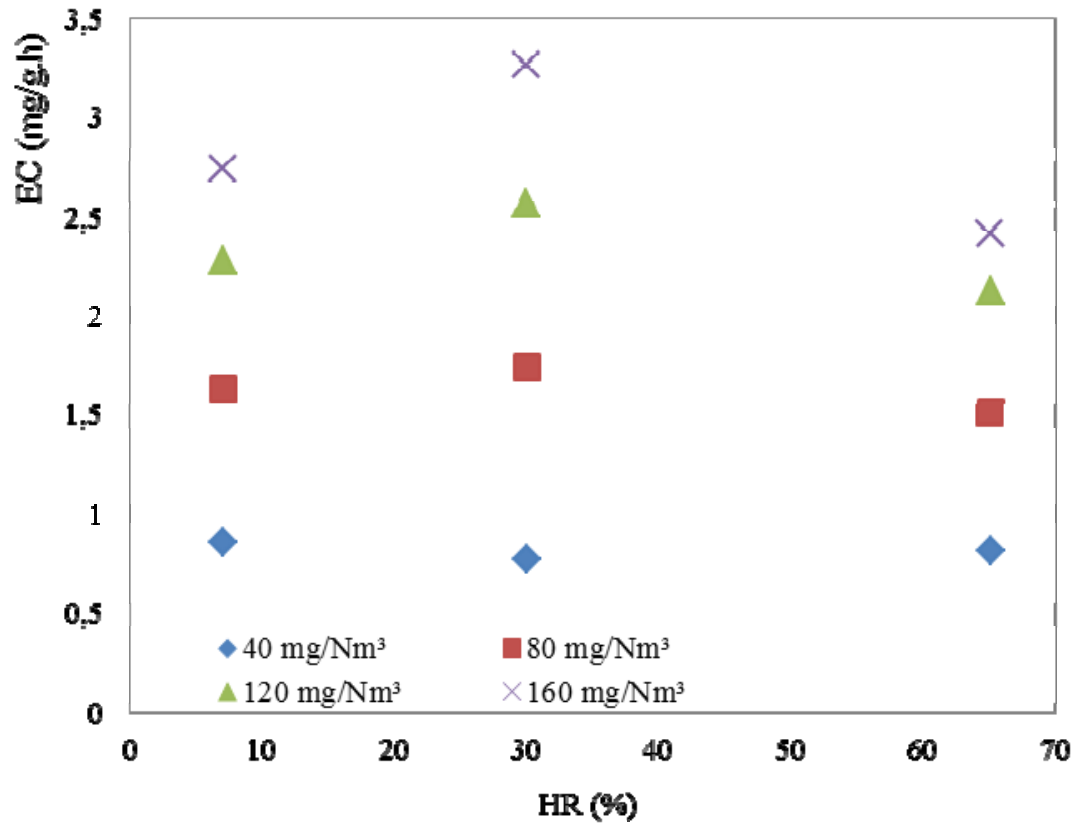

15

16 Figure 13. Variation of EC with RH at different inlet concentrations ( $\left.\mathrm{SE}=17 \mathrm{~J} \cdot \mathrm{L}^{-1}, \mathrm{Q}_{\mathrm{air}}=2 \mathrm{~m}^{3} \cdot \mathrm{h}^{-1}, \mathrm{I}=\mathbf{2 0 \mathrm { W }} \cdot \mathrm{m}^{-2}\right)$. 


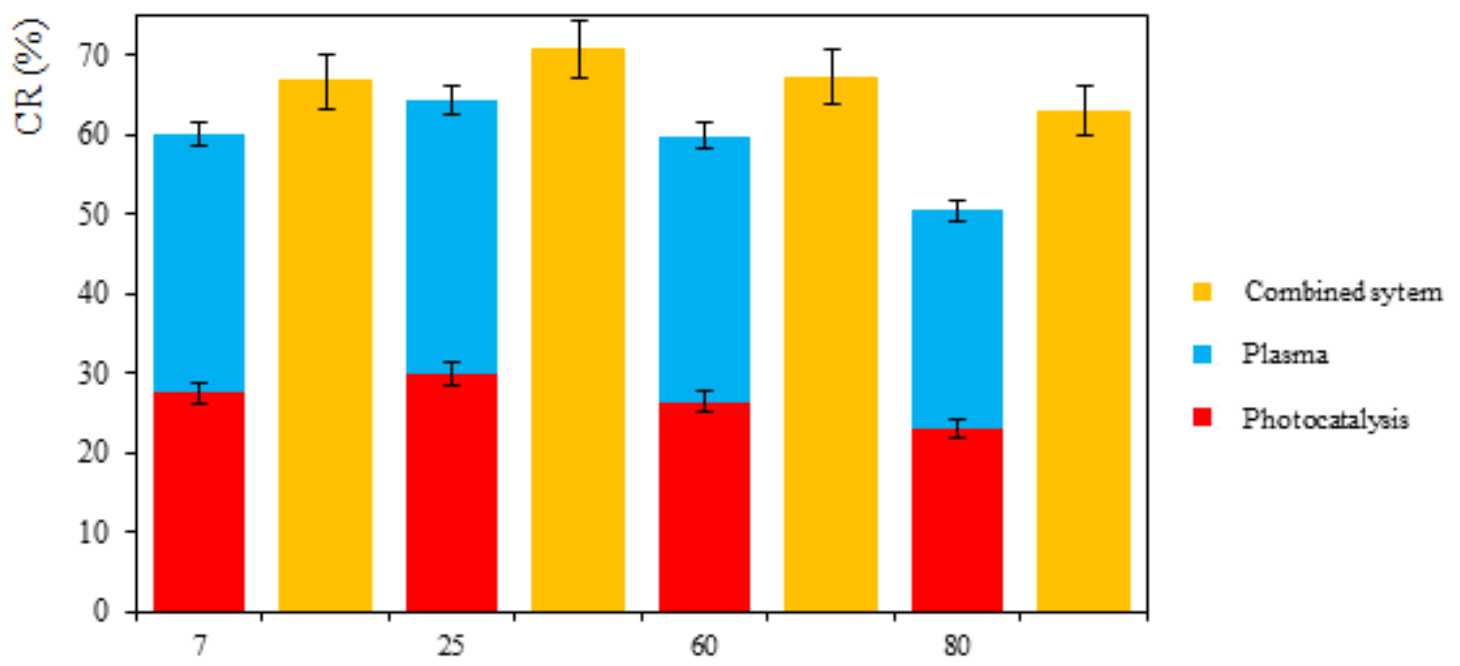




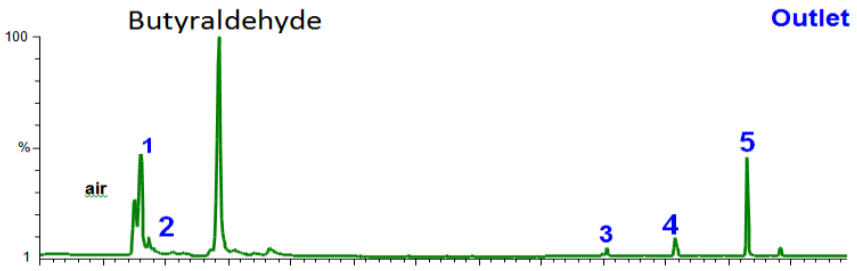




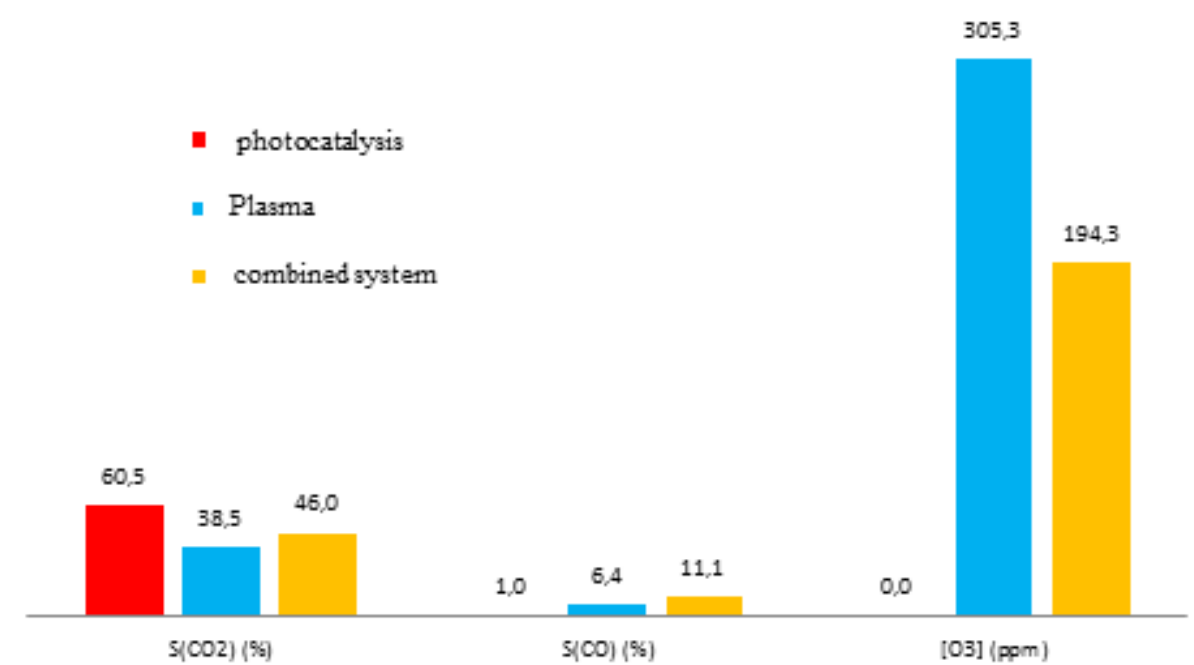

Figure 8. $\mathrm{CO}_{2}$ and $\mathrm{CO}$ selectivity's, and removal rate of oxidized butyraldehyde by photocatalysis, plasma DBD and

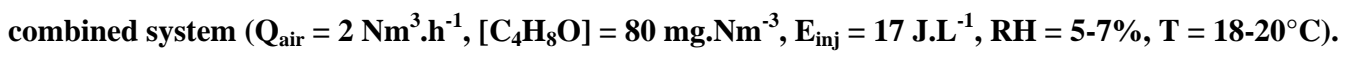




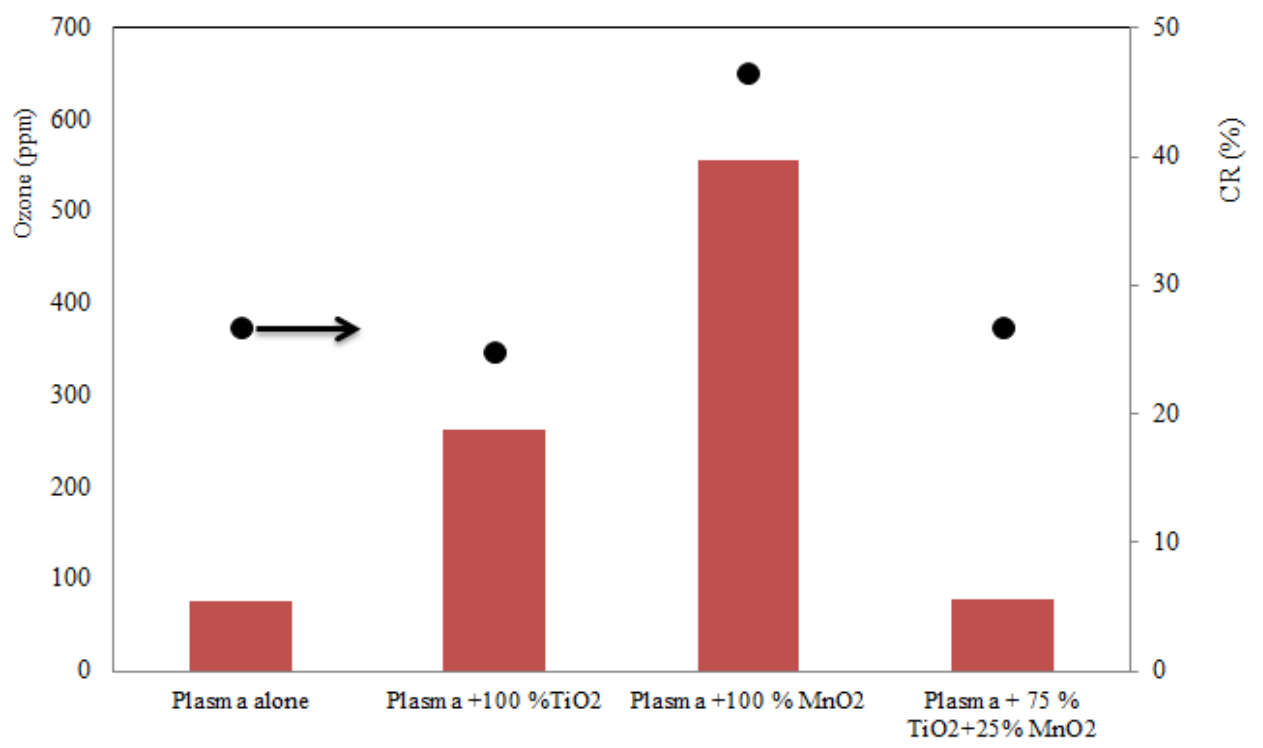

Figure 9. Effect of catalyst composition on BUTY conversion rate and the amount of formed ozone by plasma-

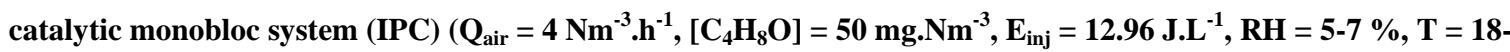
$\left.20^{\circ} \mathrm{C}\right)$. 


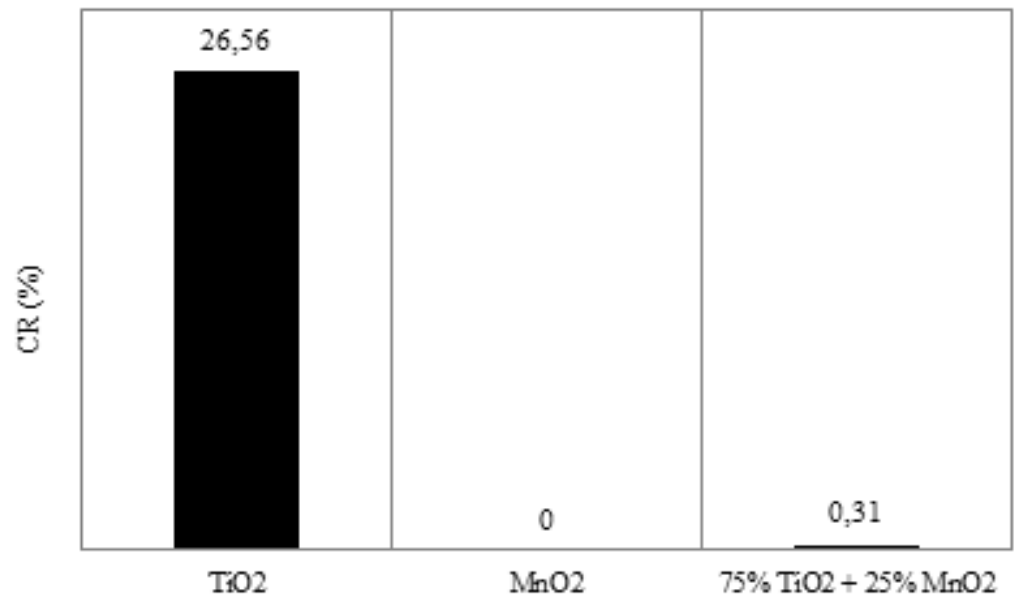

15

Figure 10. Comparison of the photocatalytic performance of different media for BUTY oxidation $\left(Q_{a i r}=4\right.$ $\mathrm{Nm}^{-3} \cdot \mathrm{h}^{-1},\left[\mathrm{C}_{4} \mathrm{H}_{8} \mathrm{O}\right]=50 \mathrm{mg} \cdot \mathrm{Nm}^{-3}, \mathrm{RH}=5-7 \%, \mathrm{~T}=\mathbf{1 8}^{-20}{ }^{\circ} \mathrm{C}$ ) 


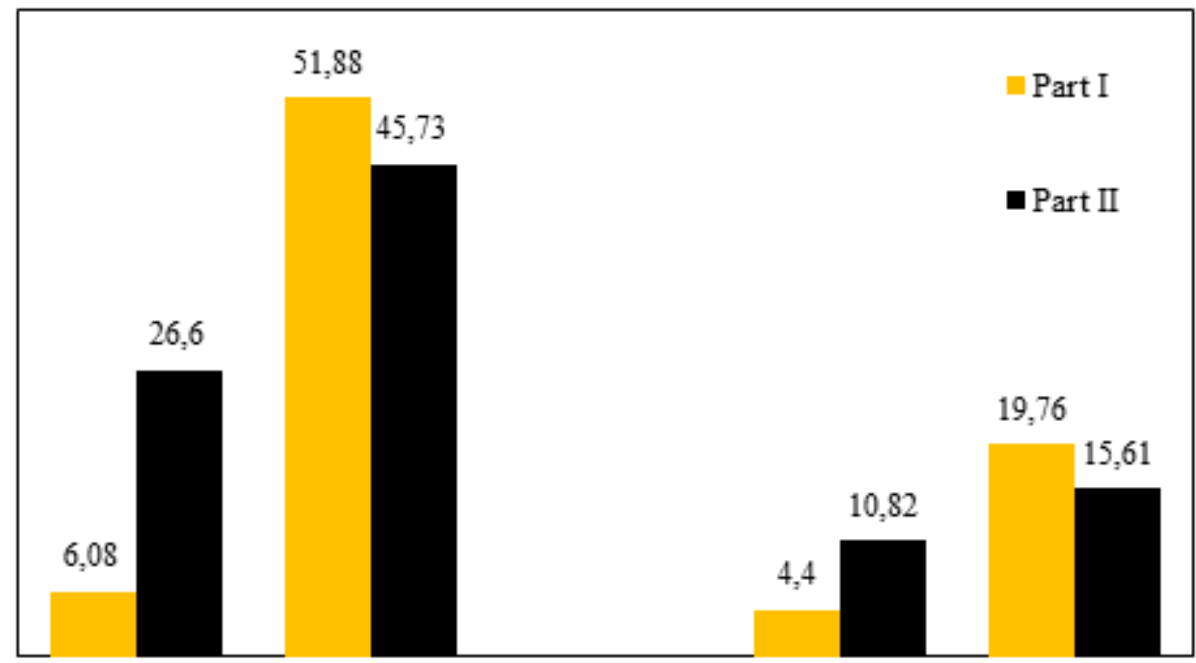

$\mathrm{RE}(\%) \quad$ ozone (ppm)

$\mathrm{RE}(\%) \quad$ ozone (ppm)

Figure 11. Effect of RH on BUTY conversion rate and ozone formation in PPC for the same BUTY inlet concentration

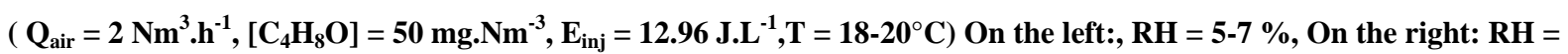
$55 \%$. 
